\title{
Multiple Linear Regression Tree Stem Volume Equations for the Estimation of Merchantable Volume of Azadirachta Indica (Neem Tree) in North-West Region of Nigeria
}

\author{
R.B. Shuaibu, J.S. Alao* \\ Department of Forestry and Wild Life Management, Faculty of Agriculture \& Agricultural \\ Technology, Federal University Dutsin-Ma, Dutsin-Ma, Katsina State, Nigeria \\ * Department of Forestry and Wild Life Management, Faculty of Agriculture, Federal University \\ Gashua, Gashua, Yobe State Nigeria \\ srabibinta@yahoo.com,rshuaibu@fudutsinma.edu.ng,*alaojs@yahoo.com
}

\begin{abstract}
Multiple linear regression tree stem volume equations were developed for Azadirachta indica in North-West region of Nigeria and in other regions with similar vegetation and environmental factors. Complete measurements of Four Hundred and twenty (420) trees were carried out in the selected plantation of Azadirachta indica within 4 states of the region which includes: Katsina State; Kano State; Zamfara State; and Sokoto State. One hundred and five (105) trees were measure from each of the four states making a total of Four Hundred and twenty (420) trees. Data were collected through non destructive sampling method with the use of Spiegel Relascope and meter tape. Variables considered for data mensuration were merchantable height, stump diameter, diameter at breast height, and diameter at top of the stem before the crown. Stump diameter (Dst) ranged from $41 \mathrm{~cm}$ to $67 \mathrm{~cm}$; diameter at breast height (dbh) ranged from $32 \mathrm{~cm}$ to $60 \mathrm{~cm}$; and Top diameter ranged from $17 \mathrm{~cm}$ to $48 \mathrm{~cm}$. Multiple linear regression analyses were conducted with the Statistical Package for Social Scientists (SPSS) version 18 to generate the tree stem volume equations. Various criteria were used to evaluate the ability of each model to predict a specified dependent variable. Five (5) multiple linear regression equations were developed and two best equations among the generated equations are as follows: $V=0.329$ $0.699(D)+0.436(D H)-0.035(H)$; and $V=1.109-2.227(D)+0.184(H)$. The $R, R$ square, SEE, F-value and RMSE are 0.99, 99\%, 0.01, 0.00004, 47149; and 0.00001, 0.96, 93\%, 0.02, 0.0005, 4051 respectively. The equation developed was fitted to the data, and the resulting equations possessed desirable statistical properties and model behaviors.
\end{abstract}

Keywords: Azadirachta indica, Data, Merchantable, Multiple, Volume Equations

\section{INTRODUCTION}

Linear regression equations are method of developing equations using linear predictor functions, and unknown regression equation parameters are estimated from the data. Multiple linear regressions are a process for modeling the relationship between a dependent variable and more than one explanatory variable (independent variable). Volume is referred to quantity and it is the common widely used measure of wood quantity in forest mensuration. Graves (1906) stated that mensuration is the determination of diameters, heights or volumes of either a standing tree or products cut there from such as sawn logs, and determination or prediction of rate of growth. Volume equation is defined as various mathematical statements applied to the determination of quantities (Shuaibu, 2014). The need to increase the supply of timber, poles, and staking materials for socio-economic development through adequate mensuration of forest stands to determine and improve the quantity and quality of stands is imperative. Adegoke et al., (2010) stated that the socio-economic development of any nation depends greatly on the efficient utilization of its natural resources. The importance of direct measurements of standing trees to obtain basic data for the development of relationships between the various dimensions of a tree and its volume which are used to estimate the volumes of other standing trees cannot be over emphasized. Clutter et al., (1983) and Husch et al., (2003) explained that the volume of the stem of a tree is considered a function of the independent variables; diameter, height, and form which are expressed as follows:

$\mathrm{V}=\mathrm{f}(\mathrm{D}, \mathrm{H}, \mathrm{F})$. Where $\mathrm{V}=$ volume, $\mathrm{D}=\mathrm{dbh}$ or stump diameter, $\mathrm{H}=$ total, merchantable, or height to some specific limit and $\mathrm{F}=$ measure of form such as the Girrard form class or absolute form quotient. 
Diameter and height measurements are very essential variable in volume determination. According to Shuaibu and Alao, (2013), Diameter of a tree is a random variable which depends on the age and height, and therefore, the distributions of tree diameter size in stands describe forest structure and can be used for the assessment of stand volume and biomass, forest biodiversity and density management.

Even though volume equations have been studied for many years, they continue to attract forest research. This is because there is no single theory in volume that can be used satisfactorily for all tree species; no single volume model is best for all purposes and volume equations are required to be increasingly accurate, flexible, valid and normal in their predictions. Also forest measurement needs to be improved because market requirements for timber, poles and fuel-wood have become more specific in recent years and volumes of current growing stock and future growth potentials are both important information for forest management.

Azadirachta indica (Neem tree) is one of the indigenized tree species whose drought tolerance, ability to survive a degree of hot and cold weather, ability to combat desertification, ability to prevent erosion, ability to improve the soil nutrients, ability to improve marginal land and adaptability has made it particularly suitable to the climate condition of North Western Region of Nigeria. Neem is useful as windbreaks and in areas of low rainfall and high wind speed, the wood is attractive in color, hard and relatively heavy. Being durable and termite resistant, neem wood is used in making fence posts, poles for house construction, furniture, and a good source of firewood. Being a hardy, multipurpose tree and fast in growth, it is appropriate for reforestation \& afforestation programs and for rehabilitating degraded, marginal, semi-arid and arid lands which is the common features of North-Western region of Nigeria. The tree's ability to re-sprout after cutting and to re-grow its canopy after pollarding makes it highly suited to pole production (National Research Council 1992). Forest mensuration had been known to be an essential activities in forest management practices, it helps in the evaluation of forest value; adequate and proper research; knowing the growth and yield of forest stands. Effective management of neem trees and stands requires information on volume of the growing stock and Sustainable forest management requires estimates of growing stock, flexible and accurate models that can determine the merchantable and total volume of tree stem. Such information guides forest managers in timber valuation as well as in allocation of forest areas for harvest (Akindele and LeMay, 2006). Little or no substantial work on tree stem volume equations for neem tree and stands in North Western Region of Nigeria has been carried out. Therefore, it is of vital importance to carry out this study now. The objective of this paper is to generate tree stem volume equations for Azadirachta indica using multiple linear regressions technique.

\section{Study Area}

The Study Area is North Western Region of Nigeria. Four (4) States from the region were randomly selected for data collection. The states are Katsina, Kano, Zamfara, and Sokoto State respectively. Katsina State is on latitude $12^{\circ} 15^{\prime} \mathrm{N}$ and longitude $7^{\circ} 30^{\prime} \mathrm{E}$. It covers an area of $24,192 \mathrm{~km}^{2}$. Kano State is on latitude $11^{\circ} 30^{\prime} \mathrm{N}$ and longitude $8^{\circ} 30^{\prime} \mathrm{E}$. It covers an area of $20,131 \mathrm{~km}^{2}$. Zamfara State is on latitude $12^{\circ} 10^{\prime} \mathrm{N}$ and longitude $6^{\circ} 15^{\prime} \mathrm{E}$. It covers an area of $39,762 \mathrm{~km}^{2}$. Sokoto State is on latitude $13^{\circ} 05^{\prime} \mathrm{N}$ and longitude $05^{\circ} 15^{\prime} \mathrm{E}$. It covers an area of $25,973 \mathrm{~km}^{2}$.

\section{Method of Data Collection}

The trees were randomly selected from plantations of Azadirachta indica in each of the state for measurements. One hundred and five (105) trees were measure from each of the four states making a total of Four Hundred and twenty (420) trees. Data were collected through non destructive sampling method with the use of Spiegel Relascope and meter tape. The following tree data were collected in each sampled plantations: Dst (stem diameter at a position of $30 \mathrm{~cm}$ above the ground level), dbh (stem diameter at a position of $1.3 \mathrm{~m}$ above the ground level), middle diameter, merchantable top diameter, and merchantable height.

\section{Method of Data Analysis}

The data collected was arranged in excel and the statistical analysis which include determination of merchantable height, changing of diameter in $\mathrm{cm}$ to metre, estimation of basal area, and volume of the collected dataset was performed using Microsoft Excel. While the Statistical Package for Social Scientists (SPSS) was used to conduct multiple regression analysis to generate equations that express merchantable tree volume as a function of stump diameter (Dst); diameter at breast height (dbh); and merchantable height. 


\section{Volume Model Generation}

In order to generate the models in this study, individual tree growth variables across all sample plantations in each of the four states was used. The tree growth variables from the four states were also pooled together to generate this models that could be used for merchantable volume estimation of Azadirachta indica. Five (5) multiple linear regression models were generated for the estimation of Azadirachta indica tree volume. In this study, the volume of the stem of a tree is considered as a function of the independent variables, stump diameter; diameter at breast height and merchantable height, which is expressed as follows:

$V=f(D s t, D$ and $H)$

Where $\mathrm{V}=$ merchantable volume, $\mathrm{Dst}=$ stump diameter, $\mathrm{D}=$ diameter at breast height, and $\mathrm{H}=$ merchantable height. The multiple linear models are as follows:

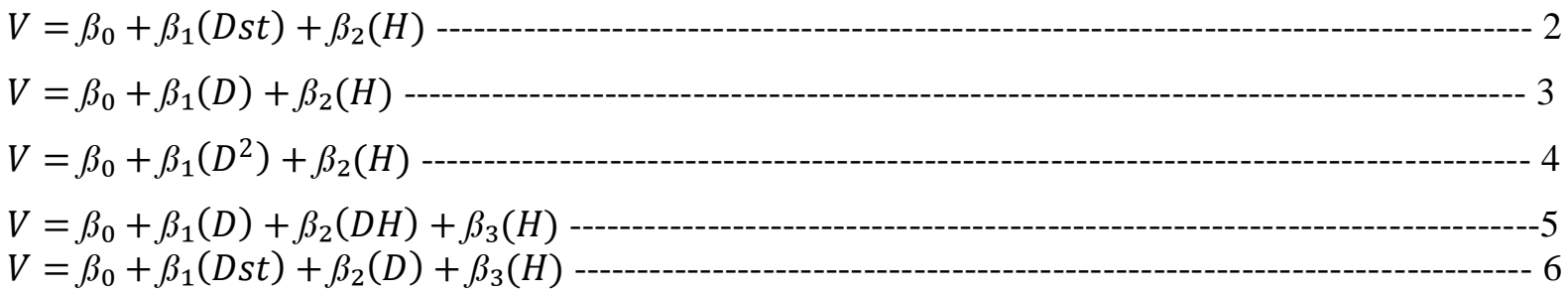

Where: $\mathrm{V}=$ merchantable tree volume in $\mathrm{m}^{3}$, Dst $=$ stump diameter, $\mathrm{D}=$ diameter at breast height, $\mathrm{H}$ $=$ merchantable tree height in meter; $\beta_{0}, \beta_{1}, \beta_{2}$ and $\beta_{3}=$ regression parameters.

\section{Assessment of the Models}

The Azadirachta tree stem volume models were assessed in order to test their plausibility and recommending those with good fit for further uses. These statistical criteria below were used:

\section{Significance of Regression}

This was used in testing the overall significance of the regression equation. The critical value of $\mathrm{F}$ (that is, F-tabulated) at $\mathrm{p}<0.05$ level of significance was compared with the F-ratio (F-calculated). Where the variance ratio (F-calculated) is greater than the critical values (F-tabulated) such equation is considered significant and can be accepted for prediction. The relationship below were used to calculate the overall significance of regression

$$
\begin{aligned}
& S^{2}=\frac{\sum_{i=1}^{n}\left(y_{i}-\bar{y}\right)^{2}}{n-1} \\
& S S_{T}=\sum_{i=1}^{n}\left(y_{i}-\bar{y}\right)^{2} \\
& M S_{T}=\frac{S S_{T}}{\operatorname{dof}\left(S S_{T}\right)}=\frac{S S_{T}}{n-1} \\
& S S_{R}=S S_{T} \\
& S S_{R}=\sum_{i=1}^{n}\left(y_{i}-\bar{y}\right)^{2}-11
\end{aligned}
$$

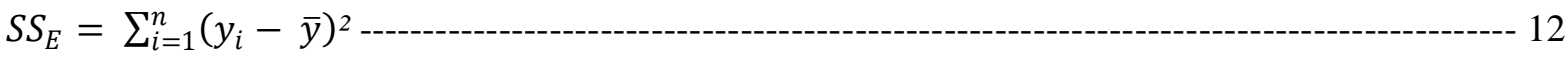

$$
\begin{aligned}
& S S_{T}=S S_{R}+S S_{E}--1 \\
& M S_{E}=\frac{S S_{E}}{\operatorname{dof}\left(S S_{E}\right)}=\frac{S S_{E}}{n-2} \\
& \sigma^{2}=\frac{S S_{E}}{n-2}---15 \\
& M S_{R}=\frac{S S_{R}}{\operatorname{dof}\left(S S_{R}\right)}=\frac{S S_{R}}{1}-(-16
\end{aligned}
$$

$\mathrm{H}_{\mathrm{O}}$ is accepted if

$F_{o}=\frac{M S_{R}}{M S_{E}}=\frac{S S_{R} / 1}{S S_{E} /(n-2)}$

$\mathrm{H}_{\mathrm{o}}$ is rejected if

$F_{0}>f_{\propto, 1, n-2}$ 
Where $\mathrm{s}^{2}=$ Sum of squares, $S S_{T}=$ the total sum of squares, $M S_{T}=$ the total mean square, $S S_{R}=$ the regression sum of squares, $S S_{E}=$ the error sum of squares, $M S_{E}=$ the error mean square, $M S_{R}=$ the regression mean square, $y_{i}=$ all the observations, $\bar{y}=$ the mean of the observation, $n-l=$ numbers of degrees of freedom, $F_{0}>f_{\propto, 1, n-2}$ is the percentile of the $\mathrm{F}$ distribution corresponding to a cumulative probability of $(1-\propto)$ and $\alpha$ is the significance level.

\section{Multiple Correlation Co-efficient}

The $(\mathrm{R})$ measures the degree of association between two variables (Y-Dependent variable and $\mathrm{X}$ Independent variable. The R- value must be high (>0.50) for the model to be considered good fit (Mead et al. 1994).

$R_{z, x y}=\sqrt{\frac{r_{x z}^{2}+r_{y z}^{2}-2 r_{x z} r_{y z} r_{x y}}{1-r_{x y}^{2}}}$

Where $\mathrm{Z}=$ dependent variable, $\mathrm{x}$ and $\mathrm{y}=$ independent variables, $\mathrm{R}=$ multiple correlation coefficient

\section{Coefficient of Determination $\left(\mathbf{R}^{2}\right)$}

The $\left(\mathrm{R}^{2}\right)$ measures the proportion of variation in the dependent variable that is explained by the behavior of the independent variable. In order for the model to be accepted, the $\mathrm{R}^{2}$ value must be high i.e $>50 \%$ (Thomas, 1977). The formula below was used to compute it.

$R^{2}=1-\frac{S S_{r e s}}{S S_{\text {tot }}}$

Where $R^{2}=$ Coefficient of determination, $S S_{\text {res }}=$ residual sum of squares, $S S_{\text {tot }}=$ total sum of squares, and $1=$ regression line

\section{Regression Standard Error of Estimate}

The value must be relatively small for the model to be considered valid.

$\sigma_{e s t}=\sqrt{\frac{\sum(Y-\bar{Y})^{2}}{N}}$

Where $\left(\mathrm{Y}-\mathrm{Y}^{\prime}\right)^{2}=$ the squared errors of prediction, $\mathrm{N}=$ observation

\section{Models Validation}

The field data from the four states were divided into two sets. The first set (calibrating set), comprised tree data from 80 trees from each of the state, making 320 trees when data from all the four states were pooled. These were used for developing the models. The second set (validating set) comprised tree data from 25 trees from each of the state, and 100 trees for the four states. These were used for validating the models. Observed volume was individually compared with predicted volume using paired-samples T-Test, simple linear regression models and ANOVA single factor. The observed volume was the dependent variable while the predicted volume was the independent variable. Statistical indices such as Absolute Bias (AB), percentage Absolute Bias (AB \%), Root Mean Square Error (RMSE) was used to assess the goodness of fit for the models:

$$
\begin{aligned}
R M S E & =\sqrt{\frac{1}{n} \sum_{i-1}^{n}\left(y_{i-} \hat{y}_{i}\right)^{2}} \\
\text { Bias } & =\frac{1}{n} \sum_{i-1}^{n}\left(y_{i-} \hat{y}_{I}\right)^{2}-10 \\
\% \text { Bias } & =100=\frac{\sum_{i}^{n}=1\left(y_{i-1} \hat{y}_{I}\right) / n}{\sum_{i}^{n}=1 \hat{y}_{I} / n}
\end{aligned}
$$

Where $y_{i}=$ observed value and $\hat{\mathrm{y}}_{I}=$ predicted value. The Root Mean Square Error (RMSE) must be relatively small for the model to be acceptable for volume estimation and for management purposes (Adekunle et al. 2013).

\section{RESULT}

Five (5) forms of multiple linear regression tree stem volume equations were developed for neem trees and stands prediction and estimation in this study. The model were assessed and validated to ensure their adequacy for the prediction of merchantable volume of neem tree. The equations 
developed are presented in table 2. The results of the assessment criteria shows that Two (2) equations (equations 4, and 2) out of the Five (5) equations was rated the best for estimation of merchantable volume of neem tree. All volume predicted were compared to observed volume using simple linear regression equation; T-test; one-way analysis of variance (ANOVA); and graphical analyses of residuals. Table 3 shows the simple linear regression result for observed versus predicted volume, table 4 shows T-test result, and table 5 shows the ANOVA results for the equations. There was high and very high correlation coefficient and coefficient of determination $\left(\mathrm{R}^{2}\right)$ for all the five equations developed and there were no significant differences in the observed versus predicted volumes for all the five equations, simple linear regression confirmed that the models had adequate fit.

A paired Student's t-test applied on the measured and predicted volume showed that all the five equations developed have p-values $>0.05$ indicating that the difference between observed and predicted volume is not significant. The results also shows that the t-test statistics for the models are less than t-critical (t-stat $<\mathrm{t}$-critical), the models therefore, has good fit.

The results of single factor ANOVA used in comparing the observed values and the predicted value showed that there were no significant differences $(p>0.05)$ between the observed and predicted equations developed, meaning the volume model developed is adequate for the estimation of merchantable volume of neem tree and stands.

\section{Validation Results of Volume Equations Generated}

The Five (5) generated models were validated with data from One-hundred (100) trees representing the data from Three hundred and twenty (320) trees which was used for the model generation. The result is presented in Table 7 and figure 1-5 shows the result of residual plots for all the five models validated.

Figure 1-5: Residual Plots for the Validation Volume Model Developed

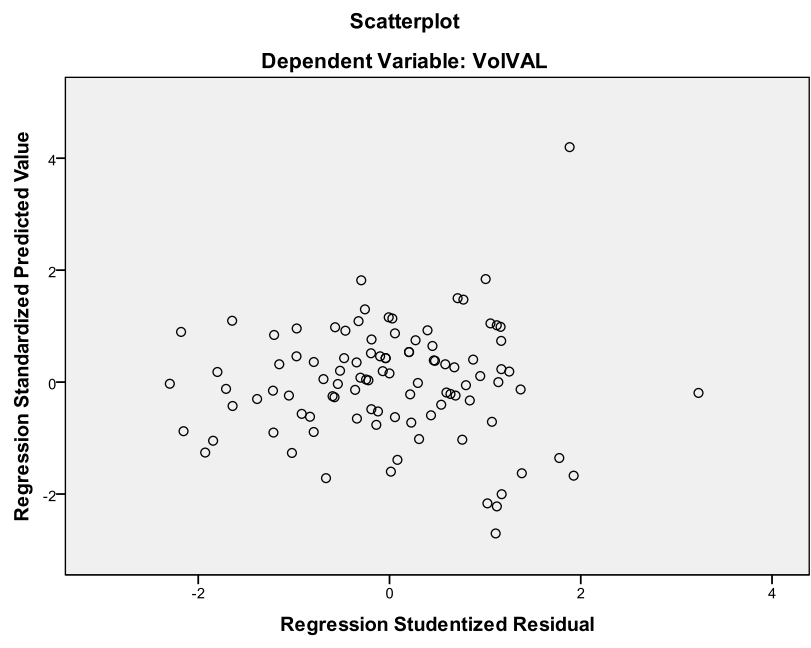

Residual Plots for Val Model 1

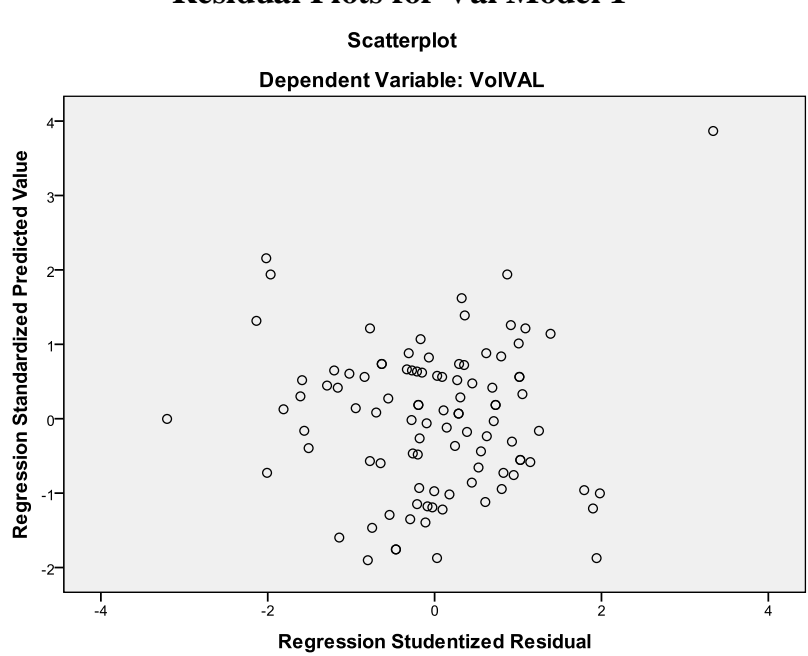

Residual Plots for Val Model 2 


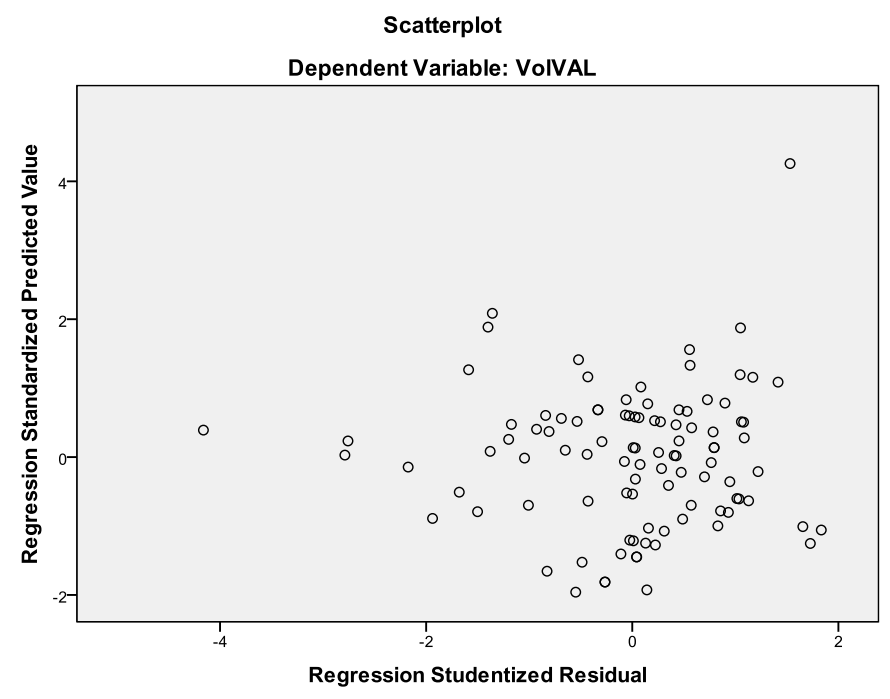

Residual Plots for Val Model 3

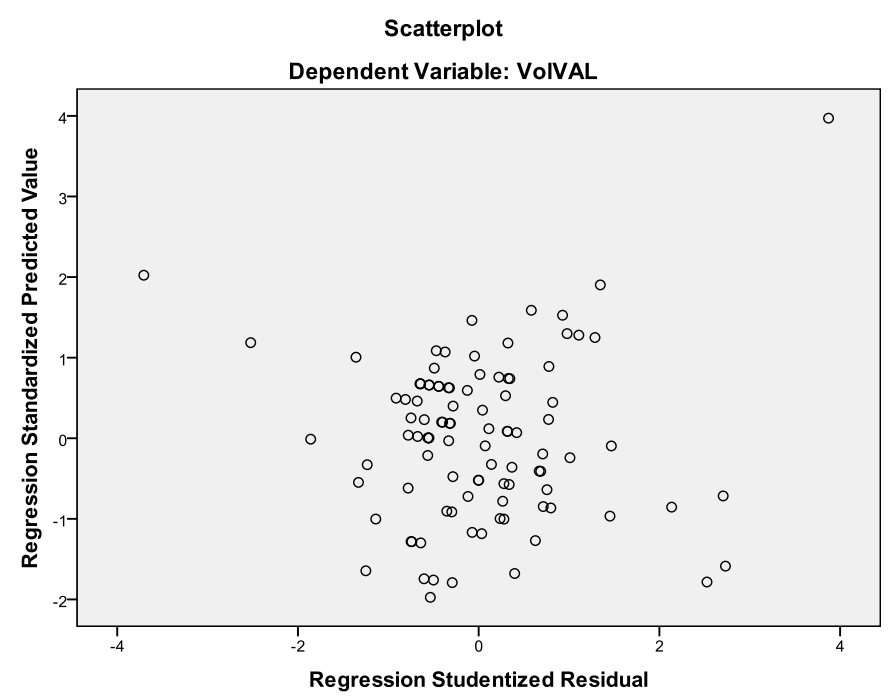

Residual Plots for Val Model 4

Scatterplot

Dependent Variable: VoIVAL

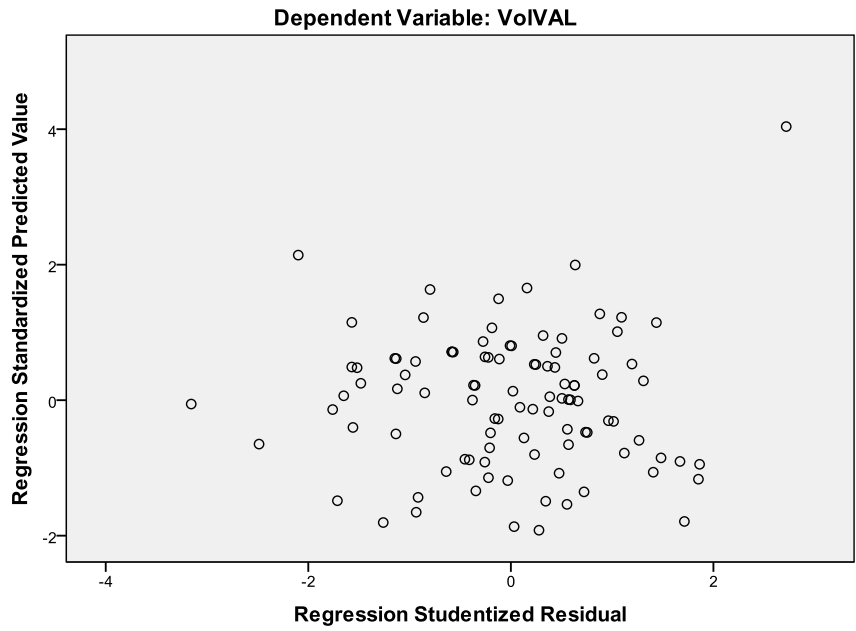

Residual Plots for Val Model 5

There was high and very high correlation coefficient and coefficient of determination $\left(\mathrm{R}^{2}\right)$ for all the models. Also, the statistical indices which include relative BIASES, \%BIASES, SEE and RMSE were used to determine the accuracy of the models and the results were very low. These values were 
relatively very small and they confirmed that the models gave accurate predictions with manageable error (Adekunle et al. 2013). The level of multicollinearity of the equations was tested with respect to both the fitting and validation data to ensure that no potential problem of multicollinearity was present. This equation is therefore, suitable when high precision and accuracy is required.

\section{DISCUSSION}

In this study the observed volume of the sample trees was calculated by applying Huber's Formulae $\left(V=S_{m} \times l\right)$. Five (5) volume models that could be used for merchantable volume estimation were developed and tested. In order to assess the accuracy of various models developed, the $\mathrm{R}^{2}$, SEE, RMSE, relative Biases, \%Biases, and SDR were calculated for each model and ranking of the complete values of the fit statistics were also included to facilitate comparison of the models. Most models tested performed similarly to each other. Residual analysis showed little differences in magnitudes of bias and precision amongst the models. The $\mathrm{R}^{2}$ result suggests that a very large proportion of the variation in tree volume is explained by diameter at breast height and merchantable height for the stands. The result of SEE, RMSE, and F-value shows that the models have good fit and are therefore recommended for merchantable tree stem volume estimation for Azadirachta indica. All the assessment criteria revealed that the generated models had good fit and the statistical fits were generally good. The use of these equations is recommended based on the results of the T-test, one way analysis of variance and simple linear regression equation of the observed versus predicted volumes. There were no significant differences between observed and predicted volumes; there was a strong relationship (high $\mathrm{R}$ values) between the observed versus predicted volumes, high $\mathrm{R}^{2}$, significant $\mathrm{F}$ ratio and small standard error of estimate. SE, RMSE, Biases and \% Biases also confirmed predictive precision, accuracy, and normality. The values were very small and similar to what were obtained by Sonmez et al. (2009) and Adam and Csalovics (2010). This was supported by the report of Adekunle (2006) that standard error of estimate is a good measure of overall predictive value of regression equations. (Glantz and Slinker (2001) also noted that it is a common measure of goodness of fit in regression models, with low values indicating better fit. The scatter-plots were consistent with the results of other statistical indices for validation. This shows that the regression assumptions were not violated. Other tree growth modeling studies, including Andreassen and Tomter (2003), Mabvurira and Miina (2002), Zhao et al. (2004), Trasobares and Pukkala (2004), and Sonmez et al (2009) also observed no constant variance of residuals, an inevitable phenomenon for forest populations due to the nature of the growth process.

The validation dataset included measurements of one-hundred (100) trees from the plantations other than those used to develop the newly-generated equations. The data are within the representative of the fitting data set. Model number four (4) yielded the lowest RMSE values in both the fitting and validation data, the RMSE value must be relatively small for the model to be suitable for high precision and accuracy. For tree growth variables, the mean dbh value was $44 \mathrm{~cm}$ for the forest stands (Table 1). The commonest diameter at breast height and merchantable height are $52 \mathrm{~cm}$ and $4 \mathrm{~m}$ respectively. The basal area per hectare in each of the forest plantation is $49.4 \mathrm{~m}^{2}$ which is more than the $24 \mathrm{~m}^{2}$ prescribed for a well stocked forest (Alder and Abayomi, 1994). Both the models for calibration and validation in this study gave negative intercept. This is in line with the findings of Avery and Burkhart (2002); they reported that merchantable volume prediction usually gives negative intercept. All the multiple linear models developed for merchantable volume estimation in this study were discovered to be very adequate for yield estimation in arid and semi-arid zone and are therefore recommended for further use.

Table1. Summary of Tree Variables Measured for Model Generation

\begin{tabular}{|l|l|l|l|l|l|}
\hline Tree variables & Tree No & Minimum & Maximum & Mean & StDv \\
\hline Merchantable Heig $(\mathrm{m})$ & 320 & 1.65 & 4.14 & 3.13 & 0.67 \\
\hline Dbase $(\mathrm{m})$ & 320 & 0.41 & 0.67 & 0.51 & 0.07 \\
\hline Dbh $(\mathrm{m})$ & 320 & 0.32 & 0.60 & 0.44 & 0.08 \\
\hline Top diameter & 320 & 0.17 & 0.48 & 0.30 & 0.09 \\
\hline Ba Dbh $\mathrm{m}^{2}$ & 320 & 0.08 & 0.28 & 0.15 & 0.06 \\
\hline Volume $\left(\mathrm{m}^{\wedge} 3\right)$ & 320 & 0.31 & 0.74 & 0.44 & 0.08 \\
\hline
\end{tabular}


Table 2. Multiple Volume Equations Generated for Azadirachta indica

\begin{tabular}{|l|l|l|l|l|l|l|}
\hline No. & Linear Models & $\mathrm{R}$ & $\mathrm{R}^{2}(\%)$ & SEE & RMSE & F-value \\
\hline 1 & $\mathrm{~V}=1.264-2.294(\mathrm{Dst})+0.167(\mathrm{H})$ & 0.89 & 80 & 0.04 & 0.001 & 625 \\
\hline 2 & $\mathrm{~V}=1.109-2.227(\mathrm{D})+0.184(\mathrm{H})$ & 0.96 & 93 & 0.02 & 0.00005 & 4051 \\
\hline 3 & $\mathrm{~V}=0.579-2.389\left(\mathrm{D}^{2}\right)+0.175(\mathrm{H})$ & 0.91 & 83 & 0.03 & 0.001 & 789 \\
\hline 4 & $\mathrm{~V}=0.329-0.699(\mathrm{D})+0.436(\mathrm{DH})-0.035(\mathrm{H})$ & 0.99 & 99 & 0.01 & 0.00004 & 47149 \\
\hline 5 & $\mathrm{~V}=1.012+0.459(\mathrm{Dst})+2.590(\mathrm{D})+0.178(\mathrm{H})$ & 0.96 & 93 & 0.02 & 0.0001 & 1,387 \\
\hline
\end{tabular}

Table 3. Regression Result for the observed versus predicted volumes

\begin{tabular}{|l|l|l|l|l|l|l|l|}
\hline No & $\mathrm{R}$ & $\mathrm{R}^{2}(\%)$ & SEE & RMSE & F-value & BIASES & $\%$ BIASES \\
\hline & & & & & & & \\
\hline 1 & 0.89 & 80 & 0.03 & 0.001 & 1117 & 0.0001 & $-1.7 \mathrm{E}-05$ \\
\hline 2 & 0.96 & 93 & 0.01 & 0.0004 & 3979 & 0.0001 & $1.05 \mathrm{E}-05$ \\
\hline 3 & 0.91 & 83 & 0.03 & 0.001 & 1531 & 0.0189 & -0.0002 \\
\hline 4 & 0.99 & 99 & 0.01 & 0.00004 & 42129 & 0.0001 & $-1.6 \mathrm{E}-05$ \\
\hline 5 & 0.96 & 93 & 0.02 & 0.0003 & 4251 & 0.0007 & $-3.9 \mathrm{E}-05$ \\
\hline
\end{tabular}

Table 4. T-test for the observed versus predicted volumes

\begin{tabular}{|l|l|l|l|l|l|}
\hline Model & df & t-Stat & t-critic & p-value & p correl \\
\hline & & & & & \\
\hline 1 & 319 & -0.35 & 1.97 & 0.728867 & 0.89 \\
\hline 2 & 319 & 0.38 & 1.97 & 0.704809 & 0.96 \\
\hline 3 & 319 & -4.59 & 1.97 & 0.077451 & 0.91 \\
\hline 4 & 319 & -1.83 & 1.97 & 0.068871 & 0.99 \\
\hline 5 & 319 & -1.46 & 1.97 & 0.146289 & 0.96 \\
\hline
\end{tabular}

Table 5. ANOVA Result for Observed versus Predicted Volume

ANOVA: Single Factor

\begin{tabular}{|c|c|c|c|c|c|c|}
\hline \multicolumn{7}{|l|}{ SUMMARY } \\
\hline Groups & Count & Sum & Average & Variance & & \\
\hline Observed volume & 320 & 140.4814 & 0.334480 & 0.00647 & & \\
\hline $\mathrm{V}=\beta_{0}+\beta_{1}(\mathrm{Dst})+\beta_{2}(\mathrm{H})$ & 320 & 140.5141 & 0.334557 & 0.005221 & & \\
\hline$V=\beta_{0}+\beta_{1}(D)+\beta_{2}(H)$ & 320 & 140.4181 & 0.334329 & 0.006224 & & \\
\hline$V=\beta_{0}+\beta_{1}\left(D^{2}\right)+\beta_{2}(H)$ & 320 & 141.5681 & 0.337067 & 0.006257 & & \\
\hline $\mathrm{V}=\beta_{0}+\beta_{1}(\mathrm{D})+\beta_{2}(\mathrm{DH})+\beta_{3}(\mathrm{H})$ & 320 & 140.4836 & 0.334485 & 0.00646 & & \\
\hline$V=\beta_{0}+\beta_{1}(\mathrm{Dst})+\beta_{2}(\mathrm{D})+\beta_{3}(\mathrm{H})$ & 320 & 140.4731 & 0.334460 & 0.006205 & & \\
\hline \multicolumn{7}{|l|}{ ANOVA } \\
\hline Source of Variation & $S S$ & $D f$ & $M S$ & $F$ & $P$-value & F crit \\
\hline Between Groups & 0.014515 & 5 & 0.002903 & 0.472837 & 0.796719 & 2.220287 \\
\hline Within Groups & 8.87781 & 1914 & 0.003531 & & & \\
\hline Total & 8.892325 & 1919 & & & & \\
\hline
\end{tabular}

Table 6. Summary of Tree Variables Measured for Validation

\begin{tabular}{|l|l|l|l|l|l|}
\hline Tree Variables & Tree No & Minimum & Maximum & Mean & StDev \\
\hline Merchantable Heig & 100 & 1.81 & 3.38 & 2.77 & 0.42 \\
\hline Dbase $(\mathrm{m})$ & 100 & 0.5 & 0.65 & 0.56 & 0.04 \\
\hline DBH $(\mathrm{m})$ & 100 & 0.43 & 0.59 & 0.5 & 0.04 \\
\hline Dtop $(\mathrm{m})$ & 100 & 0.3 & 0.46 & 0.37 & 0.04 \\
\hline BA DBH $\left(\mathrm{m}^{2}\right)$ & 100 & 0.14 & 0.27 & 0.19 & 0.03 \\
\hline Volume & 100 & 0.42 & 0.72 & 0.51 & 0.05 \\
\hline
\end{tabular}

Table 7. Validation Result

\begin{tabular}{|l|l|l|l|l|l|l|r|}
\hline Linear Models & R & $R^{2}(\%)$ & SEE & RMSE & F-value & BIASES & $\%$ BIASES \\
\hline $\mathrm{V}=1.337-2.213(\mathrm{Dst})+0.218(\mathrm{H})$ & 0.87 & 75 & 0.02 & 0.001 & 148 & 0.0003 & $-1.6 \mathrm{E}-05$ \\
\hline $\mathrm{V}=1.060-2.083(\mathrm{D})+0.195(\mathrm{H})$ & 0.97 & 95 & 0.01 & 0.00001 & 844 & 0.0002 & $1.1 \mathrm{E}-06$ \\
\hline $\mathrm{V}=0.716-1.930\left(\mathrm{D}^{2}\right)+0.222(\mathrm{H})$ & 0.86 & 74 & 0.02 & 0.001 & 139 & 0.0164 & -0.0001 \\
\hline $\mathrm{V}=0.288-0.595(\mathrm{D})+0.525(\mathrm{DH})-0.075(\mathrm{H})$ & 0.99 & 98 & 0.01 & 0.000001 & 1312 & 0.0001 & $-1.5 \mathrm{E}-05$ \\
\hline $\mathrm{V}=1.187-0.399(\mathrm{Dst})+1.819(\mathrm{D})+0.207(\mathrm{H})$ & 0.98 & 95 & 0.01 & 0.00001 & 635 & 0.0006 & $-4.7 \mathrm{E}-05$ \\
\hline
\end{tabular}




\section{CONCLUSION}

This study tested the efficacy of multiple linear regression equations for merchantable tree volume estimation of Azadirachta indica in North Western Region of Nigeria. Four hundred and twenty (420) trees were used to develop the equations. Findings of this study confirmed that there was high and very high correlation coefficient $(\mathrm{R})$; coefficient of determination $\left(\mathrm{R}^{2}\right)$ and $\mathrm{F}$-value for all the five equations developed in this study. Also, very low SEE; RMSE; Biases; \%Bias and there were no significant differences from the results of Student's t-test and single factor ANOVA in the observed versus predicted volumes for all the five equations. There was a strong positive correlation between the merchantable volume as dependent variable and diameter at breast height (dbh) and merchantable height as independent variables. Therefore, all the categories of multiple linear equations developed in this study are recommended for merchantable tree volume estimation of Azadirachta indica in North Western Region of Nigeria and in other regions with similar vegetation and environmental factors.

\section{RECOMMENDATION}

The merchantable volume of Azadirachta indica stands have been adequately described by the equations generated in this study, and the equation can be applied with relative ease.

\section{REFERENCES}

Adam H. E and Csalovics E. (2010): Integration of Remote Sensing, GIS, and Terrestrial Forest Inventory in Estimation of Acacia senegal Tree Parameters. In:Rainer Reuter (Ed), Remote Sensing for Science, Education, and Natural and Cultural Heritage, EARSeL, 2010, 6p.

Adegoke, F.F.; Akinyemi, G.O., Ige, P.O., Ogunwande, O.A., and Ogunade, J.O. (2010): Forestry Development ; A recipe for the Nation's Economic Recession. In: L., Popoola (Ed). The Global Economic Crisis and Sustainable Renewable Natural Resources Management. Proceedings of the $33^{\text {rd }}$ Annual FAN Conference, Benin City, Edo State, Nigeria.

Adekunle V. A .J. (2006): Conservation of Tree Species Diversity in Tropical Rain-Forest Ecosystem of South- West Nigeria. Journal of Tropical Forest Science, 18: 91-101.

Adekunle, V. A .J.; K. N. Nair; A. K. Srivastava; and N. K. Singh (2013): Models and Form Factors for Stand Volume Estimation in Natural Forest Ecosystems: A Case Study of Katarniaghat Wildlife Sanctuary (KGWS), Bahraich District, India. Journal of Forestry Research, 24(2): 217-226

Ahire, P. (Dec 10, 2009): 75\% of Desertification Caused by Human Activities. Daily $\quad$ Trust News Paper.

Akindele S.O, LeMay V.M. (2006): Development of Tree Volume Equations for Common Timber Species in the Tropical Rainforest Area of Nigeria Forest Ecology and Management, 226 : $41-48$.

Alder, D. and J.O. Abayomi (1994): Assessment of Data Requirement for Sustained Yield Calculations. A Consultancy Report Prepared for the Nigerian Tropical Action Plan FORMECU, Federal Department of Forestry, Ibadan.

Andreassen K and Tomter S.M. (2003): Basal Area Growth Models for Individual Trees of Norway spruce; Scots Pine; Birch and other Broad Leaves in Norway. Forest Ecology \& Management, $180,11-24$.

Avery, T.E., Burkhart, H.E., (2002): Forest Measurements, 5th Edition. McGraw-Hill Higher Education, New York, USA, p. 456.

Clutter, J. L.; Fortson J.C.; Pienaar L.V.; Brister G.H.; and Bailey R.L. (1983): Timber Management: A Quan- titative Approach, Wiley, New York.

Glantz, S.A., Slinker, B.K. (2001): Primer of Applied Regression and Analysis of Variance, $\quad 2^{\text {nd }}$ Edition. Mc Graw-Hill Inc., New York, USA, p. 949.

Graves, H. S. (1906): Forest Measuration, John Wiley, New York. 274p.

Husch, B., Beers, T.W., Kershaw Jr., J.A., (2003): Forest Mensuration, 4th ed. John Wiley and Sons, Inc., New Jersey, USA, p. 443.

Mabvurira D. and Miina J. (2002): Individual-Tree Growth and Mortality Models for Eucalyptus grandis (Hill) Maiden Plantations in Zimbabwe. Forest Ecology \& Management, 161: 231-245. 
National Research Council (1992): Marine aquaculture: Opportunities for Growth. Committee on Assessment of Technology and Opportunities for Marine Aquaculture in the United States Marine and Board Commission on Engineering and Technical System National Research Council, National Academic Press Washington, D.C. 290 p

Shuaibu, R. B., and Alao, J. S. (2013): Centrality of Forestry Education in Environmental Sustainability. ln: Labode, P.; O. Y. Ogunsanwo; V. A. J. Adekunle; I. O. Azeez; and N. O. Adewole (eds). The Green Economy: Balancing Environmental Sustainability \& Livelihoods in an Emerging Economy. Proceedings of the $36^{\text {th }}$ Annual Conference of Forestry Association of Nigeria (FAN) held in Uyo, Akwa Ibom State, Nigeria. Pp 262-267

Shuaibu, R.B. (2014): Stem Taper and Tree Volume Equations for Tectona grandis (Teak) in Agudu Forest Reserve, Nasarawa State, Nigeria. Unpublished Thesis in the Department of Forestry and Wood Technology Submitted to School of Post Graduate Studies, Federal University of Technology Akure, in Partial Fulfilment of the Requirements for the Award of Master of Agricultural Technology, (M. Agric. Tech.) Degree in Forest Inventory and Biometrics.Pp112

Sönmez T, Ercanli I, Kele S. (2009): A Distance-Independent Basal Area Growth Model for Oriental Spruce (Picea orientalis(1.) Link), Growing in Mixture with Oriental Beech (Fagus orientalis, Lipsky) in the Artvin Region. North-East, Turkey. African Journal of Agricultural Research, 4: 740-751.

Thomas J. J. (1977): An Introduction to Statistical Analysis for Economists. London: Weidenfeld and Nichol son Ltd, p.286.

Trasobares T. and Pukkala T. (2004): Using Past Growth to Improve Individual Tree Diameter Growth Models for Uneven-Aged Mixtures of Pinus sylvestris L. and Pinus nigra Arn in Catalonia, North-East Spain. Annals For Sci., 61: 409-417

Zhao D, Borders B, Wilson M. (2004): Individual-Tree Diameter Growth and Mortality Models for Bottomland Mixed-Species Hardwood Stands in the Lower Mississippi Alluvial Valley. Forest Ecology and Management, 199: 307-322.

\section{AUTHORS' BIOGRAPHY}

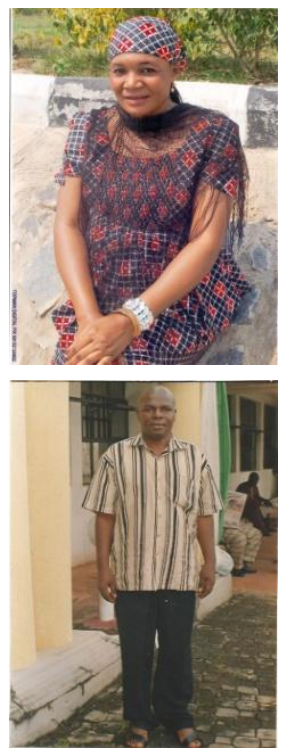

Rabi Binta Shuaibu (R. B. Shuaibu) studied Mathematics/Chemistry Education from FCT college of Education Zuba-Abuja, Nigeria in 2004. She has a Bachelor degree in Forestry and Wildlife Management in 2010 from Nasarawa State University Keffi, Nigeria. She obtained a Master degree in Forest Inventory and Biometrics in 2014 From Federal University of Technology Akure, Ondo State, Nigeria. She is presently a lecturer in the Department of Forestry and Wildlife Management, Federal University Dutsin-Ma, Katsina State, Nigeria. She has over 8 publications in local and international journals

Jonson Sunday Alao (J. S. Alao) is a professor of Forest Policy and Economics. $\mathrm{He}$ has a Bachelor degree, Master degree, and $\mathrm{PhD}$ in Forestry from the University of Ibadan, Nigeria. He has over 50 publications in local and international journals. He is presently a lecturer and Dean, Faculty of Agriculture, Federal University, Gashua, Yobe State, Nigeria. 